\title{
LEGAL VIEW OF WAYS TO USE CRYPTOCURRENCIES THROUGH THE PRISM OF MONETARY THEORY
}

The purpose of the article is to analyze the ways of using cryptocurrencies and their legal support.

Methods. The methodological basis of the study consists of the comparative law, which includes the study of the most effective foreign approaches in the field of legal regulation of cryptocurrency. In addition, in the course of the study historical and legal, system-structural, structural-functional methods, the method of ascending from abstract to specific were applied.

The results of the scientific development of the topic selected allows us to state that cryptocurrencies do not perform all the functions of money in Ukraine. At the level of administrative and legal regulation of cryptocurrencies, state measures in the field of cryptocurrencies are not defined systematically, there is no clear list of them and administrative cooperation of cryptocurrency entities is not regulated properly. The multifaceted uncertainty of the possibilities of cryptocurrencies, as well as their legal definition, leads to the existence of significant risks when used in daily money circulation. Regulation of the legal status of cryptocurrencies should become one of the directions of the economic policy of the state at the present stage. The conclusions of the study of the topic selected allow to point out that the current legal bases of implementation of state policy in adoption of the Draft Law of Ukraine "On virtual assets" № 3637 will be a successful step, as it will consolidate the legal status of cryptocurrencies as objects of law, and the state will receive additional proceeds from such transactions from cryptocurrencies. However, it needs to be refined in the following areas: define the concept of cryptocurrency at the legislative level, taking into account the economic essence of this phenomenon; and establishing clear conditions and requirements for the transparency of cryptocurrency issuance.

Cryptocurrencies are currently not a reliable store of value and a measure of value due to the high volatility of the main cryptocurrencies.

Key words: national currency, cryptocurrency, central bank, functions, legislative regulation.

JEL Classification: K20, K22, K23, K24.

\section{Natalia POLISHCHUK,}

Postgraduate Student

V. K. Mamutov Institute of Economic and Legal Research of the National Academy of Sciences of Ukraine Natalia.Polishchuk23@gmail.com orcid.org/0000-0003-3909-6460

\section{Introduction}

Mankind has constantly tried to rethink the role of money. Types and forms of money have always followed the changes in the economic system, performing the functions of a measure of value, means of circulation, payment, accumulation. In the economy of economic entities, the role of money could previously be performed by various goods: fur, salt, etc., in the post-industrial period - there are cash (paper) forms, later non-cash forms using plastic cards and smartphones. Today, in the age of digital economy, the functions of money remain the same as before, but the requirements for them have increased significantly. The modern user needs to be able to make payments independently, regardless of the time and location of the sender; make payments quickly, conveniently and with a high degree of reliability of payments; spend minimal commissions for settlements (CryptoCompare, 2015).

The use of cryptocurrencies requires a minimum of certain technical skills, so their users are not just developers and miners. Gradually, cryptocurrencies are used by other entities. For a state in which the process of investing in cryptocurrencies is particularly active, the creation of legal conditions for the circulation of cryptocurrencies is very important, because any asset requires its legal security. 
The purpose of the article is to analyze the ways of using cryptocurrencies and their legal support.

\section{Research methodology}

The methodological basis of the development was the dialectical approach, which involves consideration of the prerequisites for the formation of state regulation of ensuring cryptocurrencies as an objective reality, which is constantly evolving affected by technical, political, legal, security and other factors. In addition, in the course of the study historical and legal, system-structural, structural-functional methods, the method of ascending from abstract to specific were applied.

\section{Presenting the main material}

Under conditions of economic uncertainty, money ceases to perform its functions effectively: it is unable to maintain value (for example, Zimbabwe) or the upper threshold of money supply ceases to be limited (for example, the United States). In this situation, the main economic actors are actively looking for new ways to preserve and transfer value. The use of cryptocurrencies in monetary relations can increase the security and control over the issuance of private money.

Cryptocurrency in the vast majority of cases is not secured by any goods and is not guaranteed by the state. Thus, its value is determined both on the basis of individual perception and how it is assessed by other members of society, i. e. the level of trust in it. Existing only in the form of software code and having limited opportunities for direct exchange for goods (a function of a means of payment), cryptocurrency is used as money. Its uniqueness in relation to fiat money also lies in the fact that its limited turnover and the possibility of regulation is actually provided without the participation of the state. A computer program with a mathematical algorithm basically allows you to organize a self-regulating monetary system. The National Bank of Ukraine clarified the legality of using "virtual currency/cryptocurrency" bitcoin in Ukraine, emphasizing that according to the law only payment systems or payment system operators registered by the National Bank are allowed (National Bank of Ukraine, 2014).

It is worth considering how to use cryptocurrencies as a means of payment, a measure of value, a means of exchange, accumulation. Each function specifies specific operations and transactions backed by money. For example, a measure of value allows you to compare and compare the prices of different goods. As a medium of exchange, money makes it possible to exchange one commodity for another.

As a means of payment - to pay for services, etc. As a means of accumulation - to create stocks, acting in the form of effective demand and purchasing power deferred for the future.

The analysis results show that cryptocurrency performs the function of a means of payment due to such its properties:

- $\quad$ the ability to use it when making transactions by an unlimited number of subjects;

- the ability to transfer and create a register of information blocks using advanced technologies;

- high liquidity, allowing the use of cryptocurrency as a means of accumulation, circulation and as a means of payment (Ministry of Finance of the Republic of India, 2019).

Cryptocurrency can be one of the most promising means of payment. The purpose of creating a cryptocurrency was to develop a decentralized payment system that would be based not on trust in financial institutions, but on cryptography that can overcome the problem of double the cost, which leads to multiple use of the same tools. The disadvantage of existing payment systems, where financial institutions act as a trusted intermediary, is the high cost of transactions, necessary to prevent fraud. Cryptocurrencies based on blockchain technology, in turn, allow you to make payments without the involvement of intermediaries, which significantly reduces costs. Transactions with cryptocurrency are carried out in the shortest possible time, it is easy to exchange for any other currency, and storage can be done using a flash drive or on a cloud server. In Europe, large online stores accept it as a method of payment, for example, in Switzerland you can pay for tuition at some universities, in the US you can buy his car (Tesla), in France the government recently recognized bitcoin as an alternative payment in banks. For example, the MasterCard payment system received a patent for the technology of accelerating transactions using cryptocurrencies. The Privat 24 service balances bitcoins, providing their equivalent in hryvnia. The rate of sale and purchase of bitcoin is always available and constantly updated, and with the help of an online calculator you can always calculate the current amount and its equivalent in bitcoin or hryvnia, depending on the direction of exchange. Many large companies and online stores, such as Amazon, Microsoft, KFC Canada, Subway and many others, accept cryptocurrencies for payment along with other generally accepted means of payment (Chohan, 2018).

It should be noted that the legislation of Ukraine does not clearly define the concept of "means of payment", despite the fact that it is used in art. 35 of the Law of Ukraine "On the National Bank of 
Ukraine" and art. 3 of the Law of Ukraine "On Payment Systems and Funds Transfer in Ukraine" and is related to the definition of the hryvnia - the currency of Ukraine as the only legal tender. In accordance with part 1 of art. 99 of the Constitution of Ukraine, the currency of Ukraine is the hryvnia. According to item 3.3 of art. 3 of the Law of Ukraine "On payment systems and funds transfer in Ukraine" dated April 5, 2001 № 2346-III, part 1 of art. 3 of the Decree of the Cabinet of Ministers of Ukraine "On the system of currency regulation and currency control" dated February 19, 1993, the hryvnia as the currency of Ukraine (national currency) - is the only legal tender in Ukraine, accepted by all individuals and legal entities without any restrictions on the entire territory of Ukraine for transfers. Therefore, it is impossible to use cryptocurrency as a means of payment under Ukrainian law. If the national currency is a mandatory means of payment, the cryptocurrency is used in circulation between certain participants in the relationship, who voluntarily agree to it. The use of cryptocurrency as a means of payment can take place without the use of banking channels, which does not allow the monetary authorities to fully control cash flows in the country.

Consider whether cryptocurrency can be used as a medium of exchange. Users accumulate them in order to exchange for other goods in the future. Paper money, at one time, came to replace barter, as it proved to be a more effective means of exchange, in addition, solved the problem of trust between the parties in the agreements. If cryptocurrencies, in turn, are going to replace paper money, they will have to become an even more efficient means of exchange while still effectively addressing the issue of trust between the parties. On April 26, 2018, the European Parliament approved the AML5 Directive. This legal document establishes for the first time a legally binding definition of cryptocurrencies in the EU. Virtual currency means a digital representation of value that can be transmitted, stored or sold digitally and functions as a medium of exchange (European Parliament and Council of the European Union, 2018).

As a technology, a cryptocurrency that is no different in its purpose from other forms of money or payment systems, because it also provides commodity exchange transactions. Lubomyr Shavalyuk in his work believes that by accepting cryptocurrency as payment for goods, the store assumes currency risk due to the instability of the cryptocurrency rate. This is a disadvantage of using cryptocurrency as a medium of exchange.

On September 9, 2019, the German parliament responded to a request from the parliamentary faction of the Free Democratic Party that cryptocurrencies do not perform the basic functions of money: they can not serve as a means of exchange and payment, accumulation of value and be a unit of account. compared to transactions in fiat currencies. Also, due to high volatility, cryptocurrencies cannot be a means of accumulation (German Bundestag, 2019).

Thus, cryptocurrency serves as a medium of exchange, but this may carry certain risks and requires a thorough assessment of the country's economic potential before cryptocurrency can be used.

It is worth considering whether you can use cryptocurrency as a means of accumulation. From the earliest days of cryptocurrencies, their proponents argued that cryptocurrency was more like "digital gold" than just digital currency. However, cryptocurrency is characterized by significant volatility. To date, it is not noted that a large percentage of users use cryptocurrency for accumulation, because an asset that can lose $20 \%$ of its value per day carries great financial risks. But even with the numerous falls and changes in the exchange rate, cryptocurrency remains an investment-attractive asset. Users buy cryptocurrency on fiat funds and keep it until the appropriate time of sale at a higher rate. You can get income that is either retained or used as an investment in the real sector of the economy. These two trends - to savings and to use - were typical for 2017-2018. Cryptocurrency performs the function of accumulation best. Fixed value can be a positive moment, turning a cryptocurrency into an investment-attractive asset that is similar to stocks.

Can a cryptocurrency be a measure of value. A measure of value occurs when different kinds of goods are equated and exchanged with each other on the basis of price, i. e. the coefficient of exchange, the value of these goods is expressed in the amount of money. Due to the high volatility of cryptocurrencies, it is difficult to say whether they can be used as a measure of value. Cryptocurrencies currently cannot set prices for goods and services directly. In other words, cryptocurrencies may be accepted for certain transactions, but they are not directly related to the pricing of goods or services in the economy. In addition to stablecoins - which are the digital equivalent of the national currency of a country. For example, Tether (USDT) is the equivalent of the US dollar 1 to 1 . That is, when a certain cryptocurrency has a more stable exchange rate, their measure of value will have a positive effect, and then there will be financial players who are interested in additional income. But it can also have another effect: if powerful financial institutions are interested in investing in cryptocurrency, it can raise their price, which cannot always be interpreted as a positive factor (Likhuta et al., 2017). 
On June 11, 2020, the Verkhovna Rada of Ukraine registered the Draft Law on Virtual Assets № 3637, the bill proposes to define the concept of "virtual asset" as a special type of property that is a value in digital form. It is proposed to establish a scope, noting that virtual assets "can be transferred and exchanged and used for payment or investment purposes" (Verkhovna Rada of Ukraine, 2020).

Examining the functioning of cryptocurrencies, we can conclude that cryptocurrencies can not be a means of payment, but can serve as a means of exchange and accumulation. Cryptocurrencies are technologically different: first, they are decentralized (there is no central issuer); secondly, they are not tied to specific subjects - registrars. It complicates cryptocurrency regulation and appropriate control. The foregoing allows us to draw certain conclusions regarding cryptocurrencies as a potential element of currency values.

Thus, the criterion of value alternative means of payment, despite high volatility, to a greater or lesser extent (depending on the species) the degrees are quite consistent.

\section{Conclusions}

1. Cryptocurrency does not perform all the functions of money. The multifaceted uncertainty of the possibilities of cryptocurrencies, as well as their legal definition, leads to the existence of significant risks when used in daily money circulation.

2. Cryptocurrencies are currently not a reliable store of value and a measure of value due to the high volatility of the main cryptocurrencies.

3. Regulation of the legal status of cryptocurrencies should become one of the directions of the economic policy of the state at the present stage.

4. Adoption of the Draft Law on Virtual Assets № 3637 will be a successful step, as it will consolidate the legal status of cryptocurrencies as objects of law, and the state will receive additional proceeds from such transactions from cryptocurrencies. However, it needs to be refined in the following areas:

a) define the concept of cryptocurrency at the legislative level, taking into account the economic essence of this phenomenon;

b) establishing clear conditions and requirements for the transparency of cryptocurrency issuance.

\section{References:}

1. National Bank of Ukraine (2014). Shchodo vidnesennia operatsii z "virtualnoiu valiutoiu/kryptovaliutoiu "Bitcoin" do operatsii z torhivli inozemnoiu valiutoiu, a takozh naiavnosti pidstav dlia zarakhuvannia na potochnyi rakhunok v inozemnii valiuti fizychnoi osoby inozemnoi valiuty, otrymanoi vid prodazhu Bitcoin: lyst Natsionalnoho banku Ukrainy vid 8 hrudnia 2014 r. № 29-208/72889 [Regarding the assignment of transactions with "virtual currency/cryptocurrency "Bitcoin" to foreign exchange transactions, as well as the existence of grounds for crediting to the current account in foreign currency of a natural person foreign currency received from the sale of Bitcoin: letter of the National Bank of Ukraine dated December 8, 2014 № 29-208/72889]. Baza danykh "Zakonodavstvo Ukrainy": ofitsiinyi vebportal Verkhovnoi Rady Ukrainy Database "Legislation of Ukraine": official web portal of the Verkhovna Rada of Ukraine. Retrieved from: https://zakon.rada.gov.ua/laws/show/v2889500-14\#Text [in Ukrainian].

2. CryptoCompare (2015). How legal is Bitcoin and Crypto Currencies? Retrieved from: https://www.cryptocompare.com/coins/guides/how-legal-is-bitcoin-and-crypto-currencies/ [in English].

3. Ministry of Finance of the Republic of India (2019). Banning of Cryptocurrency \& Regulation of Official Digital Currency Bill, 2019. Retrieved from: https://www.prsindia.org/sites/default/files/bill_files/Draft $\% 20$ Banning $\% 20$ of $\% 20$ Cryptocurrency $\% 20 \% 26 \% 20$ Regulation $\% 20$ of $\% 20$ Official $\% 20$ Digital $\% 20$ Currency $\% 20$ Bill\%2C\%202019.pdf [in English].

4. German Bundestag (2019). Antwort der Bundesregierung auf die Kleine Anfrage der Abgeordneten Bettina Stark-Watzinger, Christian Dürr, Grigorios Aggelidis, weiterer Abgeordneter und der Fraktion der FDP - Drucksache 19/12136 [Answer of the Federal Government to the minor question from MPs Bettina Stark-Watzinger, Christian Dürr, Grigorios Aggelidis, other MPs and the FDP parliamentary group - printed matter 19/12136]. Retrieved from: https://dip21.bundestag.de/dip21/btd/19/130/1913053.pdf [in German].

5. Chohan, U.W. (2018). Cryptocurrencies as Asset-Backed Instruments: The Venezuelan Petro. Political Economy - Development: Fiscal \& Monetary Policy eJournal, February 7. Retrieved from: https://papers.ssrn.com/sol3/papers.cfm?abstract_id=3119606 [in English].

6. Likhuta, V. et al. (2017). Pravovoe regulirovanie kriptovalyutnogo biznesa [Legal regulation of cryptocurrency business]. Retrieved from: https://axon.partners/wp-content/uploads/2017/02/Global-Issuesof-Bitcoin-Businesses-Regulation.pdf [in Russian].

7. European Parliament and Council of the European Union (2018). Directive (EU) 2018/843 of the European Parliament and of the Council of 30 May 2018 amending Directive (EU) 2015/849 on the prevention of the use 
of the financial system for the purposes of money laundering or terrorist financing, and amending Directives 2009/138/EC and 2013/36/EU (Text with EEA relevance). Official Journal of the European Union, L 156/43, pp. 43-74. Retrieved from: https://eur-lex.europa.eu/legal-content/EN/TXT/?uri=CELEX\%3A32018L0843 [in English].

8. Verkhovna Rada of Ukraine (2020). Proekt Zakonu pro virtualni aktyvy vid 11 chervnia $2020 \mathrm{r}$. № 3637 [Draft Law on Virtual Assets of June 11, 2020 № 3637]. Baza danykh “Zakonodavstvo Ukrainy”: ofitsiinyi vebportal Verkhovnoi Rady Ukrainy - Database "Legislation of Ukraine": official web portal of the Verkhovna Rada of Ukraine. Retrieved from: https://w1.c1.rada.gov.ua/pls/zweb2/webproc4_1?pf3511=69110 [in Ukrainian].

\title{
СПОСОБИ ВИКОРИСТАННЯ КРИПТОВАЛЮТ КРІЗЬ ПРИЗМУ ГРОШОВОЇ ТЕОРІЇ: ЮРИДИЧНИЙ ПОГЛЯД
}

\author{
Наталія ПОЛІЩУК, \\ аспірант \\ Інституту економіко-правових досліджень \\ імені В. К. Мамутова Національної академії наук України \\ Natalia.Polishchuk23@gmail.com \\ orcid.org/0000-0003-3909-6460
}

\begin{abstract}
Мета статті - проаналізувати способи використання криптовалют та їх юридичне забезпечення. У статті визначено, чи можуть криптовалюти виконувати функиії грошей, а саме використовуватися як платіжний засіб, міра вартості, засіб обміну, засіб накопичення.

Методи. Методологічну основу дослідження становить порівняльний метод, який дає змогу розглянути найбільш ефективні міжнародні підходи в галузі правового регулювання криптовалют. У ході дослідження також застосовувалися історико-правовий, системно-структурний, структурно-функціональний методи, метод сходження від абстрактного до конкретного.

Результати наукового розроблення обраної теми дають змогу стверджувати, що в сучасному світі розвиток інформаційних технологій прискорюється, а законодавство не завжди встигає за розвитком технологій. Новітні фінансові технології мають свої переваги, однак за відсутності правового режиму вони формують певні ризики. Криптовалюти - це альтернатива сучасним грошам, вони можуть відіграти важливу роль у майбутньому розвитку економіки держави, однак для иього необхідно встановити правове регулювання криптовалют. Для впровадження правового режиму криптовалют важливий аналіз їхніх функиій. Під час розроблення норм, щзо стосуються правового регулювання криптовалют, вітчизняному законодавию варто враховувати зарубіжний досвід, тому у статті зроблено огляд використання криптовалют в окремих країнах.

Висновки. Зроблено висновок про важливість прийняття проєкту Закону України «Про віртуальні активи» № 3637, запропоновано розглянути рекомендащії щодо внесення до нього змін та уточнень. Визначено основні моменти, які мають бути доопраџьовані під час затвердження цього законопроєкту, яким встановлюється праве регулювання криптовалют в Украӥні. На сьогодні криптовалюти не виконують в Украйні повноцінно функиію громей, проте мають перспективи в иьому напрямі. Криптовалюти не можуть бути платіжним засобом, аджене випускаються та не підтримуються державою. Однаккриптовалюти частково виконують функиію засобу платежу, оскільки певні групи суб'єктів господарювання готові приймати їх як оплату товарів і послуг. Криптовалюти частково виконують функцію засобу обміну. Також зроблено висновок, що криптовалюти можуть мати істотні перспективи розвитку для проведення платежів, зберігання й передачі інформації насамперед завдяки інноваиійній технології, на якій трунтується ӥх функціонування. Зазначено, що регулювання правового статусу криптовалют має стати одним із напрямів економічної політики держави на сучасному етапі.
\end{abstract}

Ключові слова: національна валюта, криптовалюта, функції, центральний банк, правове регулювання. 